\title{
IgG (7 S Gamma Globulin) Metabolism in Hypogammaglob- ulinemia: Studies in Patients with Defective Gamma Globulin Synthesis, Gastrointestinal Protein Loss, or Both *
}

\author{
Thomas A. Waldmann † and Paul J. Schwab \\ (From the Metabolism Service, National Cancer Institute, Bethesda, Md. 20014)
}

The factors that control the rates of gamma globulin synthesis and catabolism and thus regulate the body pool of gamma globulin are not well understood. Although antigenic stimulation is a major factor regulating the synthesis of immunoglobulins by plasma cells (1-3), other factors such as the metabolic rate (4) and the serum concentration of gamma globulin (5-11) modify gamma globulin metabolism.

The availability of patients with hypogammaglobulinemia presents an opportunity to investigate the role played by the serum gamma globulin concentration in the regulation of gamma globulin synthesis and catabolism in man. Hypogammaglobulinemia may be secondary to a defect in gamma globulin synthesis, to excessive gamma globulin catabolism, or to urinary or gastrointestinal loss of this protein. The defect in gamma globulin synthesis is in some cases a congenital hereditary disorder limited largely to males, whereas in other patients it is an acquired defect in gamma globulin synthesis, usually idiopathic, but occasionally secondary to neoplasms including multiple myeloma, chronic lymphocytic leukemia, and thymoma (12).

The survival of gamma globulin has been studied in patients with defective gamma globulin synthesis and extreme hypogammaglobulinemia by determining the rate of decline of the serum gamma globulin concentration after the infusion of exogenous normal gamma globulin. In 16 of the 17 patients studied by this technique (12 18), the gamma globulin survival $t_{1}$ ranged from 30 to 70 days. In one patient studied by Seltzer,

\footnotetext{
* Submitted for publication March 3, 1965; accepted May 27, 1965.

† Address requests for reprints to Dr. Thomas A. Waldmann, Metabolism Service, National Cancer Institute, Bethesda, Md. 20014.
}

Baron, and Toporek (15), the survival $t_{1}$ was 12 days. No normal subjects could be studied by this technique, since such subjects have a high endogenous serum gamma globulin concentration. The survival of gamma globulin in normal subjects has, however, been studied with $\mathrm{I}^{131}$-gamma globulin. The $t_{1}$ of survival in these studies ranged from 17 to 32 days $(9,19)$, suggesting that the survival of gamma globulin was prolonged in patients with hypogammaglobulinemia due to defective synthesis. In accord with this conclusion, Solomon, Waldmann, and Fahey (9) and Andersen (20) found that the survival of gamma globulin was prolonged in some patients with a reduced concentration of this protein, secondary to chronic lymphocytic leukemia, multiple myeloma, or macroglobulinemia. However, Lang, Schettler, and Wildhack (21), Owen, McKenzie, and Huizenga (22), and Koblet, Digglemann, Barandun, and Kaser (23) found a comparable survival of $\mathrm{I}^{181}$-gamma globulin in control subjects and patients with hypogammaglobulinemia. Bronsky, Dubin, and Kushner (18) using sulfur ${ }^{85}$. labeled amino acids found short gamma globulin survivals of 5,8 , and 25 days compared to albumin survivals of over 40 days in agammaglobulinemic patients.

Holman, Nickel, and Sleisenger (24) and Andersen (20) found that the survival of gamma globulin was short in patients with excessive gastrointestinal albumin loss (exudative enteropathy). In the present study, the metabolism of $I^{181}$-labeled normal albumin and gamma globulin was investigated in 14 control subjects, 7 patients with exudative enteropathy, and 9 patients with hypogammaglobulinemia due to defective synthesis. The total body protein pools as well as the rates of albumin and gamma globulin synthesis and catabolism were measured. 


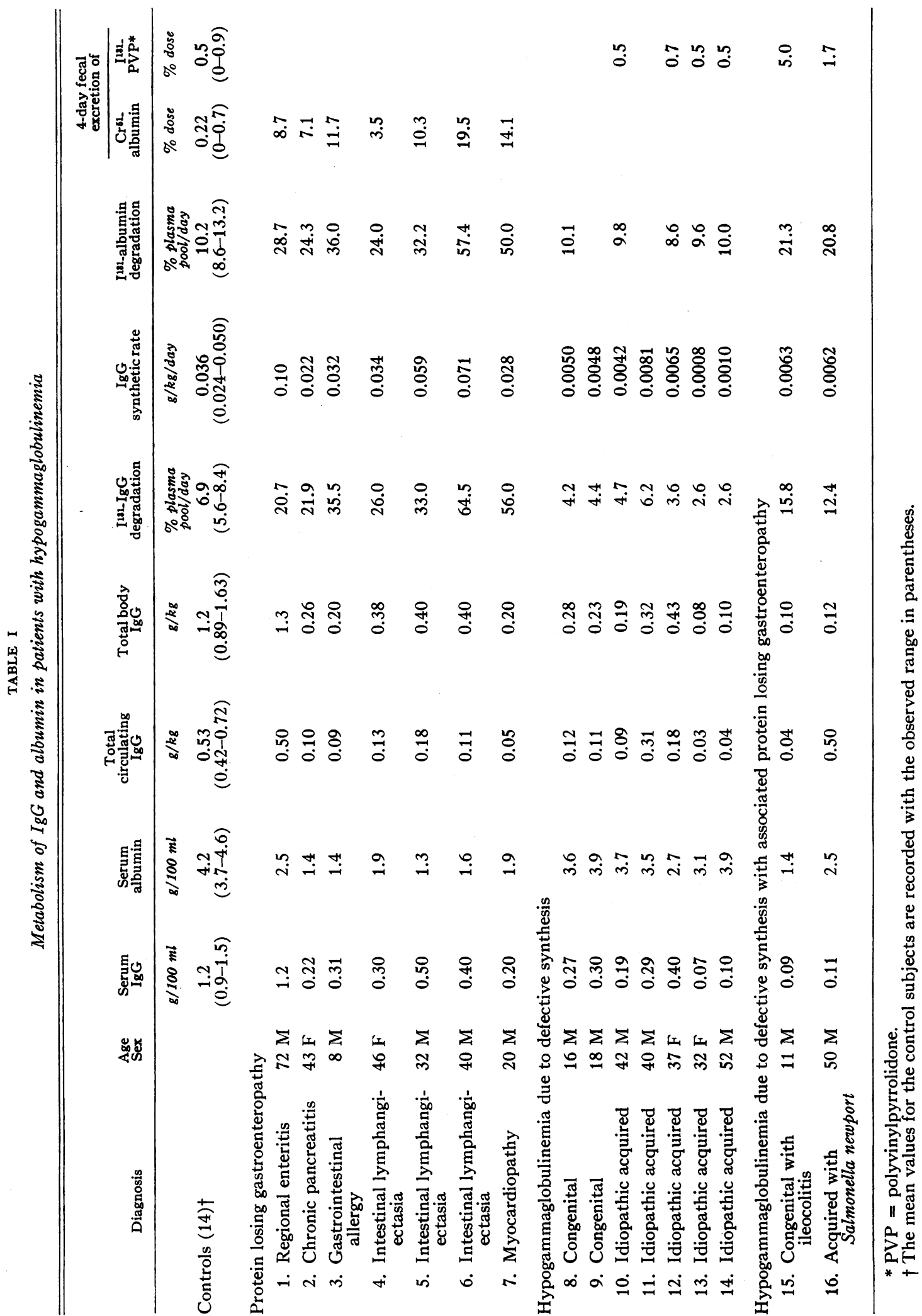




\section{Methods}

Patients studied. IgG (7 S gamma globulin) metabolism was studied in two categories of patients with hypogammaglobulinemia, those with defective synthesis and those with excessive protein loss. The latter group included seven patients with excessive gastrointestinal protein loss, marked hypoalbuminemia, moderate edema, and slight diarrhea. The diagnosis of excessive gastrointestinal protein loss was established with $\mathrm{I}^{\text {1st }}$-albumin and $\mathrm{Cr}^{51}$-albumin (25) (Table I). Each of the patients had a marked increase in the fractional catabolic rate of $\mathrm{I}^{131}$-albumin and excessive fecal excretion of $\mathrm{Cr}^{51}$ after intravenous administration of $\mathrm{Cr}^{51}$-albumin. The subjects included one patient with regional enteritis, one with chronic pancreatitis and severe malabsorption, and one patient with a generalized myopathy with associated cardiomegaly, congestive heart failure, and secondary intestinal protein loss similar to that previously described with constrictive pericarditis (26). One patient had gastrointestinal protein loss, anemia, eosinophilia, and growth retardation, apparently secondary to gastrointestinal allergy (27). Three patients had intestinal lymphangiectasia, a syndrome in which gastrointestinal protein loss is associated with lymphocytopenia, dilated lymphatic channels of the small bowel, and generalized lymphatic disorders $(24,28)$.

Nine patients with hypogammaglobulinemia (agammaglobulinemia) due to defective production were studied. This group included three patients with congenital hypogammaglobulinemia of the sex-linked recessive type and six subjects with idiopathic acquired hypogammaglobulinemia. Two of the patients, one with congenital hypogammaglobulinemia and one with idiopathic acquired hypogammaglobulinemia, had associated gastrointestinal disorders. The patient with congenital hypogammaglobulinemia had ileocolitis; the patient with acquired hypogammaglobulinemia had a chronic Salmonella newport infection and a sprue-like syndrome with diarrhea and steatorrhea. These two patients were shown to have associated gastrointestinal protein loss by $\mathrm{I}^{131}$-albumin and $\mathrm{I}^{120}$-polyvinylpyrrolidone (PVP) (29) and are considered separately from the other seven patients with agammaglobulinemia.

Fourteen normal adults ranging in age from 21 to 45 served as controls for the $I^{131}$-albumin and $I^{131}$-gamma globulin studies. Normal values for the $\mathrm{Cr}^{5 \mathrm{~s}}$-albumin and $\mathrm{I}^{121}$-PVP tests were determined in 60 and 10 subjects, respectively, with diseases not affecting the gastrointestinal tract.

All patients were hospitalized during the 4- to 6-week period of the turnover study. Each of the patients had an adequate diet with an intake of over 1,500 calories. None of the patients was febrile or had proteinuria. Liver function tests, including alkaline phosphatase, serum bilirubin, serum glutamic-pyruvate transaminase, and cephalin flocculation, were normal in each of the subjects. None of the patients were taking medications.

Preparation and labeling of normal gamma globulin $(I g G)$ for turnover studies. Gamma globulin for la- beling was prepared by curtain electrophoresis from normal serum with a model B Beckman curtain electrophoresis apparatus. After an 8-hour period of equilibration of the curtain apparatus with a $0.033 \mathrm{M} \mathrm{pH} 8.6$ barbital buffer, a sample of normal serum diluted $2: 1$ with the barbital buffer was applied to the curtain at a rate of 0.5 to $1 \mathrm{ml}$ per hour. The separation was performed with a current of $35 \mathrm{ma}, 700 \mathrm{v}$ for 24 hours. The effluent was collected in a series of 32 tubes, and the protein concentrations of the samples were estimated from their optical density at a wavelength of $280 \mathrm{~m} \mu$. The tubes containing the initial protein peak (gamma globulin) were pooled and concentrated by ultrafiltration. Cohn Fraction V (Red Cross albumin) was used to prepare the $\mathrm{I}^{151}$ albumin.

The gamma globulin and albumin preparations were iodinated with reducing agent-free $\mathrm{Na}-\mathrm{I}^{181}$ by the iodine monochloride method of McFarlane (30). The final product contained from 0.3 to 1 mole of iodine per mole of protein. Over $99 \%$ of the final products were precipitable with $10 \%$ phosphotungstic acid. The iodinated protein was passed through a $0.22-\mu$ Millipore filter, and $70 \mathrm{mg}$ of sterile human albumin was added per $\mathrm{ml}$ to prevent damage due to self-radiation. All radioactivity in the $\mathrm{I}^{181}$ gamma globulin preparations migrated as a gamma globulin on paper electrophoresis. On passage of the iodinated gamma globulin over DEAE-cellulose according to the method described by Fahey and Horbett (31), over 98\% of the radioactivity was found in the area of the peak of the IgG molecules with no label in the gamma macroglobulin $(\operatorname{IgM})$ area.

Experimental protocol. Each patient received $0.5 \mathrm{ml}$ of Lugol's solution every 8 hours throughout the period of study to inhibit thyroidal uptake of $I^{181}$ released by the breakdown of the labeled protein. Approximately $100 \mu \mathrm{c}$ of $\mathrm{I}^{131}$-protein was administered intravenously from a calibrated syringe to each patient. Blood samples were obtained without stasis from the patients at $15-$ and 30 minute intervals, after administration of the iodinated protein, and then three to five times a week for the next 20 days, and placed in bottles with EDTA anticoagulant. Urine and feces were collected in 24-hour lots throughout the entire study. The samples were assayed for radioactivity with appropriate standards in a gamma ray welltype scintillation counter with a thallium-activated sodium iodide crystal.

The total serum proteins were determined by a biuret method. The serum samples were analyzed weekly throughout the study period by paper eletcrophoresis with a $\mathrm{pH} 8.6$ barbital buffer to determine the serum albumin and gamma globulin concentrations (32). The IgG concentration was also estimated by the quantitative immune precipitin method described by Fahey and McKelvey (33). There was no significant change in the serum gamma globulin or albumin concentrations during the study in any of the patients.

The $\mathrm{I}^{131}$-protein turnover data were analyzed according to a modification of the metabolic clearance technique described by Berson, Yalow, Schreiber, and Post (34), and Pearson, Veall, and Vetter (35). The follow- 
ing equations summarize the calculations: Plasma volume $(P V)=$ administered radioactivity/radioactivity per milliliter of plasma at zero time (extrapolated from 15and 30-minute values). Total circulating $\operatorname{IgG}=\mathrm{PV} \times$ serum IgG concentration. Radioactivity retained in body $=$ activity administered minus cumulative radioactivity in urine and stool. Fraction of body IgG intravascular $=$ $(\mathrm{PV} \times$ plasma radioactivity per milliliter $) /$ radioactivity retained in body (this fraction is determined after completion of equilibration of $\mathrm{I}^{131}$-IgG among the body compartments after days 6 to 8 ). Total body IgG pool = total circulating $\mathrm{IgG} /$ fraction of body IgG intravascular. Fraction of circulating IgG catabolized per day = radioactivity excreted in urine and stools per 24-hour period/ mean circulating radioactivity during the same period. This fraction was determined for each collection period, and the mean value for the days 3 to 20 was used in the following calculation: IgG turnover $=$ total circulating IgG $\times$ fraction of circulating IgG catabolized per day. Since the concentration of the serum proteins remained constant throughout the study period, the patients were felt to be in the steady state, and the rate of gamma globulin synthesis is considered equal to the value for gamma globulin turnover.

Demonstration of gastrointestinal protein loss. $\mathrm{I}^{131}$ PVP or $\mathrm{Cr}^{51}$-albumin was used to demonstrate gastrointestinal protein loss according to methods previously described $(25,29)$. The patients received 25 to $35 \mu \mathrm{c}$ of the labeled macromolecule intravenously from a calibrated syringe. The stools passed during the subsequent 4 days were collected as a single lot in a 1-gallon stainless steel can, brought to a constant volume, and homogenized by agitation on a shaker. The homogenized sam- ples were counted with an appropriate standard on a gamma ray scintillation counter. The results are expressed as a percentage of the dose of administered isotope excreted in the 4-day feces collection.

\section{Results}

Data obtained in the $\mathrm{I}^{131}$-gamma globulin ( $\mathrm{IgG}$ ) turnover studies are recorded in Table I. Control subjects had a total circulating IgG pool of 0.42 to $0.72 \mathrm{~g}$ per $\mathrm{kg}$ and a total body IgG pool of 0.89 to $1.63 \mathrm{~g}$ per $\mathrm{kg}$. From 5.6 to $8.4 \%$ of the plasma pool of IgG was catabolized per day, corresponding to a $t_{\frac{1}{2}}$ of survival derived from the serum curves of 18.9 to 24.1 days. From 0.024 to $0.050 \mathrm{~g}$ per $\mathrm{kg}$ of IgG was turned over (synthesized) each day.

Patients with excessive gastrointestinal protein loss. The serum IgG concentration and total circulating and total body pools of IgG were reduced in six of the seven patients. The fractional catabolic rate was markedly elevated for both $\mathrm{I}^{131}$-albumin and $I^{131}-\operatorname{IgG}$ for each of these patients. The fractional catabolic rates for albumin and IgG were comparable for a given patient. The rate of IgG synthesis was slightly reduced in the patient with pancreatitis and malabsorption, was normal or slightly increased in five patients, and was

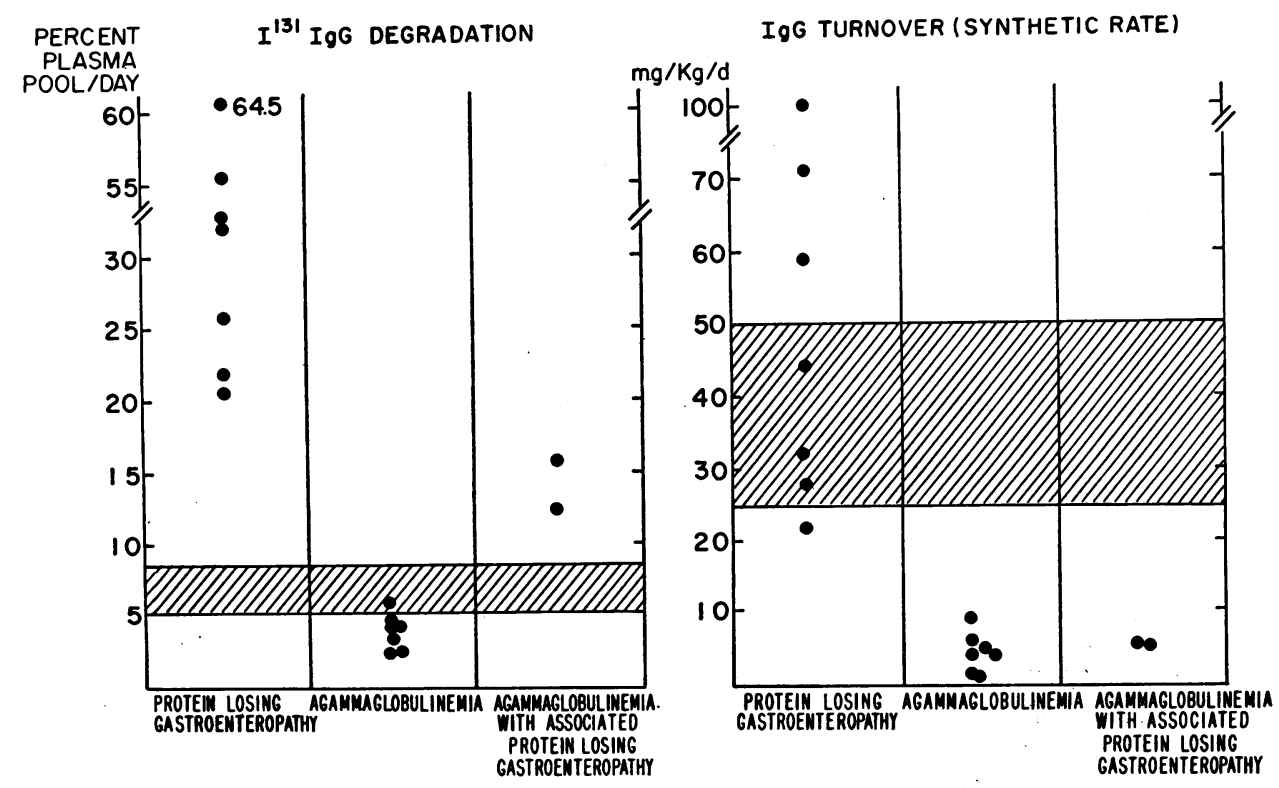

Fig. 1. The IgG catabolic and synthetic rates in patients with gastrointestinal PROTEIN LOSS, AGAMMAGLOBULINEMIA, AND COMBINED DISORDERS. The range of normal values for 14 subjects is indicated by the crosshatched areas. 


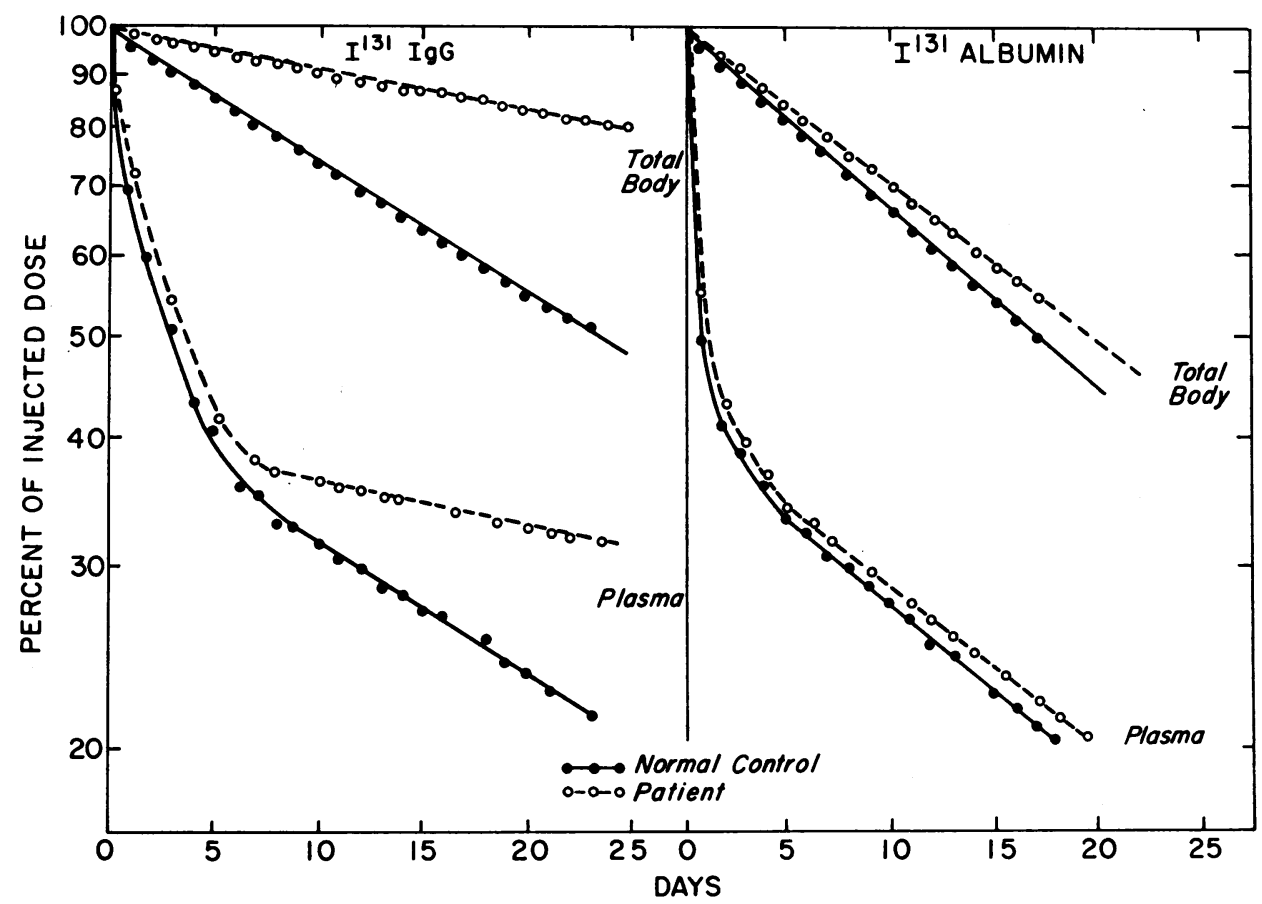

Fig. 2. The survival of $I^{131}$-gamma globulin and albumin in patient 14 with agammaGLOBULINEMIA DEMONSTRATING A PROLONGED GAMMA GLOBULIN SURVIVAL AND NORMAL ALBUMIN SURVIVAL.

markedly increased to three times normal in the patient with regional enteritis.

Hypogammaglobulinemia due to defective synthesis (agammaglobulinemia). Each of the nine patients with agammaglobulinemia had a reduced serum concentration of IgG and had markedly reduced total circulating and total body IgG pools. The IgG synthetic rate was from 2 to $20 \%$ of normal in these nine patients. In the patients without associated gastrointestinal protein loss, the fractional catabolic rate of IgG was below the normal range in six of the seven patients with a mean of $4.0 \%$ of the intravascular pool catabolized per day (Table I, Figures 1 and 2). The mean $t_{1}$ of survival of $\mathrm{IgG}$ derived from the serum curves was 38 days with a range of 28 to 71 days. The fractional catabolic rate for $\mathrm{I}^{131}$-albumin was normal in the five patients studied.

The fractional catabolic rate of both $\mathrm{I}^{131}$-IgG and $\mathrm{I}^{131}$-albumin was increased in the two patients with hyposynthetic hypogammaglobulinemia and associated gastrointestinal protein loss.

\section{Discussion}

Gamma globulin metabolism in patients with gastrointestinal protein loss. Six of the seven patients with gastrointestinal protein loss in the present study had decreased serum albumin and gamma globulin concentrations, markedly increased fractional catabolic rates of both albumin and gamma globulin, and normal or slightly increased gamma globulin synthetic rates. Hypogammaglobulinemia has been commonly associated with hypoalbuminemia in patients with excessive enteric protein loss $(20,24,28)$. All 45 of the patients with excessive gastrointestinal protein loss secondary to intestinal lymphangiectasia, gastrointestinal allergy, constrictive pericarditis, gastric rugal hypertrophy, nontropical sprue, and Whipple's disease seen at the National Institutes of Health have had a serum gamma globulin concentration below $0.7 \mathrm{~g}$ per $100 \mathrm{ml}$. In contrast, the nine patients with regional enteritis and ulcerative colitis and gastrointestinal protein loss had serum gamma globulin concentrations from 0.8 to $1.7 \mathrm{~g}$ per $100 \mathrm{ml}$. In general, loss of proteins from 


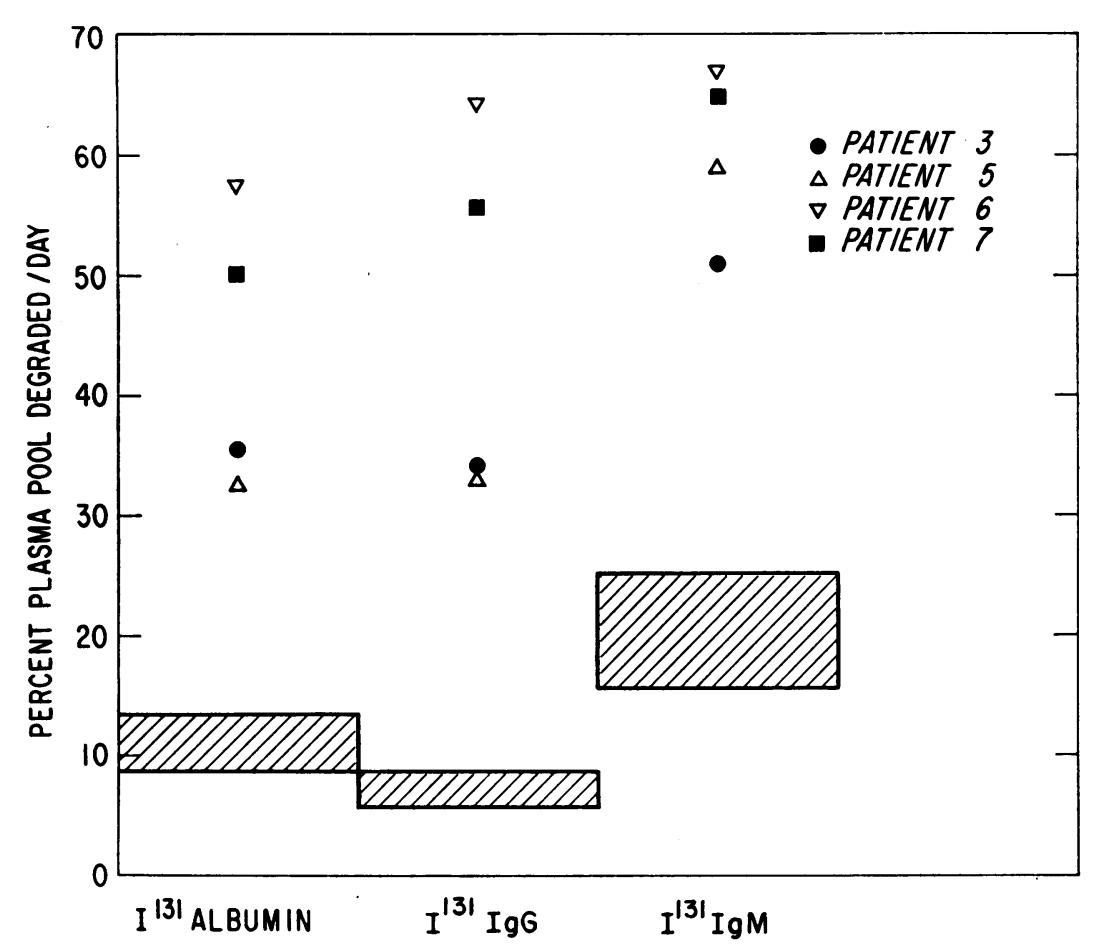

Fig. 3. The fractional catabolic rates of albumin, IgG (7 S gamma globuLIN), AND IGM (GAMMA MACROGLOBULIN) IN FOUR PATIENTS WITH GASTROINTESTINAL PROTEIN LOSS. The range of normal values is indicated by the crosshatched areas.

the body should be considered when there is a reduction in the serum concentration of both albumin and gamma globulin, proteins formed in different tissue sites. The possibility of gastrointestinal protein loss should be investigated in all patients with hypoalbuminemia and hypogammaglobulinemia where loss of these proteins is not secondary to proteinuria, plasmapheresis, or exudative dermatitis. Although the majority of such patients with idiopathic hypoalbuminemia and hypogammaglobulinemia will have significant gastrointestinal protein loss, a similar protein pattern may be occasionally observed in patients with neoplastic diseases involving the lymphocytes or plasma cells or in patients with congenital or idiopathic acquired hypogammaglobulinemia and secondary liver disease, malnutrition, or active inflammatory disease (36).

The fractional catabolic rates for both albumin and gamma globulin were markedly increased in each of the seven patients with exudative enteropathy in agreement with the findings of Holman and associates (24) and Andersen (20), sug- gesting that substantial quantities of gamma globulin are lost into the intestinal tract in this syndrome. In the present study the increase in the fractional catabolic rate over normal was quite comparable for albumin, IgG, and gamma macroglobulin (IgM) (mol wt 1,000,000) for a given patient with exudative enteropathy (Figure 3 ). ${ }^{1}$ These findings suggest that in these patients, the proteins studied were not lost selectively into the intestinal tract on the basis of size but that there was bulk loss of plasma itself or of material with a comparable protein composition. The finding that plasma proteins of different sizes are lost into the intestinal tract at similar rates in exudative enteropathy contrasts with the urinary protein loss in the nephrotic syndrome, where the smaller serum proteins are lost preferentially and the macroglobulins are lost into the urine only when there is extreme renal damage $(38,39)$.

The role of gamma globulin concentration in the

1 The Irs-gamma macroglobulin turnover studies on these patients have been reported previously (37). 
control of gamma globulin synthesis. In the present study the synthetic rate of $\mathrm{IgG}$ was normal or slightly elevated in six of the seven patients with exudative enteropathy and was markedly elevated only in the patient with regional enteritis. There thus appears to be little compensatory increase in the synthesis of $\mathrm{IgG}$ in response to loss of this protein. Similarly, there was little or no increase in the rate of synthesis of IgG in patients with hypogammaglobulinemia and nephrosis (40) or of gamma $_{1}$-macroglobulin $(\operatorname{IgM})$ in patients with gastrointestinal protein loss and associated reduced IgM levels (37). The capacity for gamma globulin synthesis far exceeds that seen in these patients with excessive gastrointestinal protein loss, since patients with malaria have been shown to have up to five times the normal gamma globulin synthetic rate (6). Thus it appears that the rate of synthesis of the immune globulins is not significantly controlled by their serum concentration or pool size, but can be accelerated by other factors such as antigenic exposure.

Gamma globulin metabolism in agammaglobulinemia. In each of the patients with agammaglobulinemia in the present study, the primary disorder was a defect in gamma globulin synthesis. The synthesis of gamma globulin was reduced to 2 to $20 \%$ of the normal level. In contrast to the patients with hypogammaglobulinemia secondary to excessive gastrointestinal protein loss, these patients with nonproductive hypogammaglobulinemia had a markedly reduced ability to synthesize specific antibodies in response to antigenic challenge, had negligible isohemagglutinin titers, and had a decrease or absence of plasma cells (39). Many of the patients with defective gamma globulin synthesis have recurrent infections and associated chronic sinusitis, bronchitis, bronchiectasis, arthritis, and in 15 to $40 \%$ of the cases unexplained gastrointestinal tract disorders resembling sprue or ileocolitis $(36,41)$. Two of the nine patients with defective gamma globulin synthesis, in the present study, had associated gastrointestinal disorders with associated loss of proteins into the intestinal tract. After therapy of the patient with ileocolitis with prednisolone and of the patient with a sprue-like syndrome and Salmonella newport infection with a glutin-free diet and antibiotics, there was a return to normal serum albumin concentration and survival but persistent extreme hy- pogammaglobulinemia. We felt that the primary disorder in these two patients was a defect in gamma globulin synthesis but that there was a secondary disorder of the intestinal mucosa with consequent general enteric loss of serum proteins. The presence of secondary gastrointestinal protein loss in patients with deficient production of antibodies has been previously observed $(24,36$, 42) and may be a possible explanation for the occasional short gamma globulin survivals previously reported in some patients with agammaglobulinemia.

The remaining seven patients with agammaglobulinemia in the present study had a significantly reduced $\mathrm{I}^{131}$-IgG fractional catabolic rate. The five patients in this group studied with $\mathrm{I}^{131}$. albumin had a normal fractional catabolic rate for albumin. A parallel situation has been seen in a patient with analbuminemia where there was a markedly reduced fractional catabolic rate for albumin and a normal fractional catabolic rate for IgG (43). Thus the survival of albumin and IgG may vary independently of each other, suggesting that at least part of the catabolism of these proteins is by pathways unique for the given protein and that nonspecific factors, such as the bulk loss of serum into the intestinal tract postulated by others $(44,45)$, are not normally the major or sole mechanism of catabolism of these serum proteins.

The pathogenesis of the decreased fractional catabolic rate of IgG in agammaglobulinemic patients. The decreased fractional catabolic rate of $\mathrm{I}^{131}-\mathrm{IgG}$ seen in the agammaglobulinemic patients without secondary enteric protein loss might be explained by 1) an altered distribution of the IgG with a decreased percentage of the body pool in the catabolic site (i.e., the plasma pool or a pool in rapid equilibrium with it),2) a defect in the catabolic pathways for this protein accompanying the defect in synthesis, or 3) a manifestation of a basic pattern of IgG metabolism in which the fractional catabolic rate of IgG is directly correlated with and controlled by the serum concentration or total body pool of IgG. In line with the possibility of altered distribution of the gamma globulin accompanying changes in gamma globulin concentration, Andersen and Bjørneboe (46) found a marked difference from normal in the distribution of this protein between the intravascular pools and ex- 
travascular pools in hyperimmunized rabbits. They felt that although there was a marked reduction in the half-time of survival of gamma globulin in hyperimmunized rabbits compared to normal rabbits, there was a comparable fraction of the intravascular pool catabolized in both groups. In our study, however, and those reported by others, there was no difference in the distribution of IgG between the intra- and extravascular pools between normal patients and animals and those with agammaglobulinemia or with hypergammaglobulinemia due to hyperimmunization or multiple myeloma $(7,9,47)$.

The second hypothesis is that the reduced fractional catabolic rate of IgG seen in these patients with agammaglobulinemia may represent a defect in the catabolic pathways for this protein associated with the defect in synthesis. Such a disorder occurs in some patients with analbuminemia. In analbuminemic patients there was a marked prolongation of albumin survival as well as an almost complete defect in albumin synthesis $(43,48-50)$. In two of the three patients with analbuminemia infused with sufficient albumin to return the albumin pool to normal, the albumin survival remained markedly prolonged $(43,49)$, but in the third patient the survival of albumin returned to normal levels (50). There is, however, no direct evidence of a defect in gamma globulin catabolism in patients with agammaglobulinemia.

There is considerable evidence that is in accord with the third hypothesis, which postulates a direct relationship between the fractional catabolic rate of $\operatorname{IgG}$ and the serum concentration of this protein. In accord with this hypothesis, the fractional catabolic rate of IgG was decreased in the subjects of the present study with hyposynthetic hypogammaglobulinemia, as well as in subjects previously reported with a reduction in IgG concentration secondary to decreased synthesis associated with chronic lymphocytic leukemia, multiple myeloma, or macroglobulinemia $(9,20)$. The fractional catabolic rate of IgG was increased in most subjects with an elevated IgG concentration associated with chronic infection (6), liver disease (5), or multiple myeloma (7-9). A similar correlation between fractional catabolic rate and serum gamma globulin concentration has been noted in the mouse, where there was a reduction in the fractional catabolic rate of gamma globulin in germ free hypogammaglobulinemic animals (51) and an increase in the fractional catabolic rate in animals that were hyperimmunized or had gamma globulin-producing tumors (52). It has been shown by Fahey and Robinson (10) and Sell (11) that the fractional catabolic rate of $\mathrm{I}^{131}$-IgG in mice is specifically related to the concentration of IgG and not secondary to other factors such as the rate of gamma globulin synthesis or the number of plasma cells. In their studies the fractional catabolic rate of IgG was significantly increased in mice infused with IgG from a number of animal sources but not in those animals infused with albumin or gamma macroglobulin ( $\operatorname{IgM})$. The basic mechanism resulting in the direct correlation of IgG and its fractional catabolic rate has not been elucidated. There may be induction of specific catabolic enzymes with an increase in the concentration of IgG. Alternatively, there may normally be a saturable system protecting IgG molecules from catabolism. As the concentration of IgG increases, a lower fraction of the total number of IgG molecules would be protected by this saturable system, and the survival of IgG would be reduced. Just such a saturable protection system in the form of specific IgG receptors on the walls of pinocytotic vacuoles has been suggested not only as the mechanism for the correlation of IgG survival and concentration but also as the mechanism for the specific transport of IgG across the placenta and across the small intestinal mucosa of many species of newborn animals (53).

The correlation between serum concentration and fractional catabolic rate has so far been noted only with IgG and perhaps albumin, and the survival of a number of other serum proteins appears to be independent of their serum concentration or total body pool size. Gamma ${ }_{1}$-macroglobulin (IgM) survival has been shown to be essentially the same in normal controls as in patients with markedly reduced IgM levels in agammaglobulinemia or markedly increased levels in macroglobulinemia of Waldenström (37). Similarly, the survivals of fibrinogen (54), ceruloplasmin (55), and $\beta_{2} A$-globulin $(\operatorname{IgA})(56)$ have been shown to be independent of the serum concentration of these proteins.

Although the data in the present study are in accord with the hypothesis that there is a corre- 
lation between the fractional catabolic rate of gamma globulin and the serum concentration, further work is clearly necessary to determine the mechanism involved.

\section{Summary}

The metabolism of gamma globulin (IgG) was studied in seven patients with gastrointestinal protein loss, nine patients with agammaglobulinemia, and 14 control subjects. There was a reduction in the serum concentration and total body pool size of IgG in six of the seven patients with gastrointestinal protein loss studied. The fractional catabolic rate for IgG was markedly increased in each of these patients. In general, the increase in the fractional catabolic rate over normal was quite comparable for albumin, IgG, and gamma macroglobulin (IgM) for a given patient, suggesting that there was bulk loss of plasma or material with a comparable protein composition into the intestinal tract. The IgG synthetic rate was normal, or slightly increased, in six of the patients and markedly increased in only the one patient with regional enteritis. This suggests that a reduced serum IgG concentration is not a potent stimulus for IgG synthesis and that other factors, such as exposure to antigens, are the major stimuli to IgG production. The primary disorder in the patients with agammaglobulinemia was a defect in gamma globulin synthesis. Two of the nine patients developed associated gastrointestinal disorders with secondary gastrointestinal protein loss and short $\operatorname{IgG}$ and albumin survivals. Six of the seven remaining patients with agammaglobulinemia had a reduced fractional catabolic rate of IgG with a normal fractional catabolic rate of albumin. The pathogenesis of this reduced fractional catabolic rate of IgG in patients with agammaglobulinemia is discussed.

\section{Acknowledgments}

The authors wish to thank Mr. William Briner of the Radiopharmacy Service, Clinical Center, National Institutes of Health, for assistance in labeling the protein preparations and to acknowledge the many helpful discussions with Dr. John L. Fahey, Immunology Branch, National Cancer Institute.

\section{References}

1. Askonas, B. A., and R. G. White. Sites of antibody production in the guinea pig. The relation between in vitro synthesis of anti-ovalbumin and gamma globulin and distribution of antibody-containing plasma cells. Brit. J. exp. Path. 1956, 37, 61.

2. Coons, A. H., E. H. Leduc, and J. M. Connolly. Studies on antibody production. I. A method for the histochemical demonstration of specific antibody and its application to a study of the hyperimmune rabbit. J. exp. Med. 1955, 102, 49.

3. Nossal, G. J. V. Antibody production by single cells. Brit. J. exp. Path. 1958, 39, 544.

4. Dixon, F. J., D. W. Talmage, P. H. Maurer, and M. Deichmiller. The half-life of homologous gamma globulin (antibody) in several species. J. exp. Med. 1952, 96, 313.

5. Havens, W. P., Jr., J. Dickensheets, J. N. Bierly, and T. P. Eberhard. The half-life of $I^{100}$ labeled normal human gamma globulin in patients with hepatic cirrhosis. J. Immunol. 1954, 73, 256.

6. Cohen, S., I. A. McGregor, and S. Carrington. Gamma-globulin and acquired immunity to human malaria. Nature (Lond.) 1961, 192, 733.

7. Lippincott, S. W., S. Korman, C. Fong, E. Stickley, W. Wolins, and W. L. Hughes. Turnover of labeled normal gamma globulin in multiple myeloma. J. clin. Invest. 1960, 39, 565.

8. Gabuzda, T. G. The turnover and distribution of $\mathrm{I}^{182}$ labeled myeloma and macroglobulin proteins. $\mathrm{J}$. Lab. clin. Med. 1962, 59, 65.

9. Solomon, A., T. A. Waldmann, and J. L. Fahey. Metabolism of normal $6.6 \mathrm{~S} \gamma$-globulin in normal subjects and in patients with macroglobulinemia and multiple myeloma. J. Lab. clin. Med. 1963, 62, 1.

10. Fahey, J. L., and A. G. Robinson. Factors controlling serum $\gamma$-globulin concentration. J. exp. Med. 1963, $118,845$.

11. Sell, S. Evidence for species' differences in the effect of serum $\boldsymbol{\gamma}$-globulin concentration on $\boldsymbol{\gamma}$-globulin catabolism. J. exp. Med. 1964, 120, 967.

12. Gitlin, D., and C. A. Janeway. Genetic alterations in plasma proteins of man in The Plasma Proteins, F. W. Putnam, Ed. New York, Academic Press, 1960, vol. 2, p. 407.

13. Bruton, O. C., L. Apt, D. Gitlin, and C. A. Janeway. Absence of serum gamma globulin. Amer. J. Dis. Child. 1952, 84, 632.

14. Young, I. I., W. Q. Wolfson, and C. Cohn. Studies in serum proteins. Agammaglobulinemia in the adult. Amer. J. Med. 1955, 19, 222.

15. Seltzer, G., S. Baron, and M. Toporek. Idiopathic hypogammaglobulinemia and agammaglobulinemia. Review of the literature and report of a case. New Engl. J. Med. 1955, 252, 252.

16. Martin, C. M., R. S. Gordon, W. R. Felts, and N. B. $\mathrm{McCullough}$. Studies on gamma globulin. I. Distribution and metabolism of antibodies and gamma 
globulin in hypogammaglobulinemic patients. J. Lab. clin. Med. 1957, 49, 607.

17. Wiener, A. S., and E. B. Gordon. Studies on the human serum gamma globulin: I. Half-life and rate of production. J. Lab. clin. Med. 1957, 49, 258.

18. Bronsky, D., A. Dubin, and D. S. Kushner. The persistence in the blood of the radioactive label of albumins, gamma globulins, and globulins of intermediate mobility. VII. Uptake and die-away plots of $\mathrm{S}^{35}$ into serum albumins and gamma globulins after oral administration of labeled methionine in idiopathic hypogammaglobulinemia and multiple myeloma. J. Lab. clin. Med. 1959, 53, 665.

19. Cohen, S., and T. Freeman. Metabolic heterogeneity of human $\gamma$-globulin. Biochem. J. 1960, 76, 475.

20. Andersen, S. B. Metabolism of gammass-globulin in secondary hypogammaglobulinemia. Amer. J. Med. 1963, 35, 708.

21. Lang, N., G. Schettler, and R. Wildhack. Uber einen Fall von "Agammaglobulinamie" und das Verhalten parenteral zugefuhrten radioaktiv markierten Gammaglobulins in Serum. Klin. Wschr. 1954, 32, 856.

22. Owen, C. A., Jr., B. F. McKenzie, and K. A. Huizenga. Turnover of gamma globulin in a patient with agammaglobulinemia as measured by radioiodinated human gamma globulin. J. appl. Physiol. 1956, 8, 654.

23. Koblet, H., H. Diggelmann, S. Barandun, and $H$. Kaser. Personal communication.

24. Holman, H., W. F. Nickel, Jr., and M. H. Sleisenger. Hypoproteinemia antedating intestinal lesions, and possibly due to excessive serum protein loss into the intestine. Amer. J. Med. 1959, 27, 963.

25. Waldmann, T. A. Gastrointestinal protein loss demonstrated by ${ }^{{ }^{11}} \mathrm{Cr}$-labelled albumin. Lancet 1961, 2, 121.

26. Davidson, J. D., T. A. Waldmann, D. S. Goodman, and R. S. Gordon, Jr. Protein-losing gastroenteropathy in congestive heart failure. Lancet 1961, $1,899$.

27. Waldmann, T. A., R. D. Wochner, L. Laster, and R. S. Gordon, Jr. In preparation.

28. Waldmann, T. A., J. L. Steinfeld, T. F. Dutcher, J. D. Davidson, and R. S. Gordon, Jr. The role of the gastrointestinal system in "idiopathic hypoproteinemia." Gastroenterology 1961, 41, 197.

29. Gordon, R. S., Jr. Exudative enteropathy: abnormal permeability of the gastrointestinal tract demonstrable with labelled polyvinylpyrrolidone. Lancet 1959, 1, 325.

30. McFarlane, A. S. Efficient trace-labelling of proteins with iodine. Nature (Lond.) 1958, 182, 53.

31. Fahey, J. L., and A. P. Horbett. Human gamma globulin fractionation on anion exchange cellulose columns. J. biol. Chem. 1959, 234, 2645.

32. Jencks, W. P., M. R. Jetton, and E. L. Durrum. Paper electrophoresis as a quantitative method. Serum proteins. Biochem. J. 1955, 60, 205.
33. Fahey, J. L., and E. M. McKelvey. Quantitative determination of serum immunoglobulins in antibody agar plates. J. Immunol. 1965, 94, 84.

34. Berson, S. A., R. S. Yalow, S. S. Schreiber, and J. Post. Tracer experiments with $\mathrm{I}^{181}$ labeled human serum albumin: distribution and degradation studies. J. clin. Invest. 1953, 32, 746.

35. Pearson, J. D., N. Veall, and H. Vetter. A practical method for plasma albumin turnover studies. Strahlentherapie Sonderbande 1958, 38, 290.

36. Waldmann, T. A., and L. Laster. Abnormalities of albumin metabolism in patients with hypogammaglobulinemia. J. clin. Invest. 1964, 43, 1025.

37. Barth, W. F., R. D. Wochner, T. A. Waldmann, and J. L. Fahey. Metabolism of human gamma macroglobulins. J. clin. Invest. 1964, 43, 1036.

38. Blainey, J. D., D. B. Brewer, J. Hardwicke, and J. F. Soothill. The nephrotic syndrome. Diagnosis by renal biopsy and biochemical and immunological analyses related to the response to steroid therapy. Quart. J. Med. 1960, 29, 235.

39. Fahey, J. L., A. S. Solomon, and T. A. Waldmann. Comparison of the serum protein changes in exudative enteropathy, nephrotic syndrome and severe hypo (A) gammaglobulinemia. In preparation.

40. Gitlin, D., C. A. Janeway, and L. E. Farr. Studies on the metabolism of plasma proteins in the nephrotic syndrome. I. Albumin, $\boldsymbol{\gamma}$-globulin and ironbinding globulin. J. clin. Invest. 1956, 35, 44.

41. Squire, J. R. Hypogammaglobulinemia in the United Kingdom, 1956-61. Proc. Roy. Soc. Med. 1962, 55, 393.

42. Vesin, P., S. Troupel, J. Acar, H. Renault, G. Desbuquois, and R. Cattan. Entéropathie avec perte de protéines et stéatorrhee: Etude par le PVP_-181 et la trioléine- $\mathrm{I}^{181}$ : Action du régime sans gluten. Bull. Soc. méd. Hôp. Paris 1960, 76, 261.

43. Waldmann, T. A., R. S. Gordon, Jr., and W. Rosse. Studies on the metabolism of the serum proteins and lipids in a patient with analbuminemia. Amer. J. Med. 1964, 37, 960.

44. Armstrong, F. B., S. Margen, and H. Tarver. Plasma protein, VII. Site of degradation of serum albumin. Proc. Soc. exp. Biol. (N. Y.) 1960, $103,592$.

45. Wetterfors, J., R. Gullberg, S.-O. Liljedahl, L.-O. Plantin, G. Birke, and B. Olhagen. Role of the stomach and small intestine in albumin breakdown. Acta med. scand. 1960, 168, 347.

46. Andersen, S. B., and M. Bjфrneboe. Gamma globulin turnover in rabbits before and during hyperimmunization. J. exp. Med. 1964, 119, 537.

47. Catsoulis, E. A., E. C. Franklin, M. Oratz, and M. A. Rothschild. Gamma globulin metabolism in rabbits during the anamnestic response. J. exp. Med. 1964, 119, 615.

48. Bennhold, H. Kongenitale Defektdysporteinamine. Verh. dtsch. Ges. inn. Med. 1956, 62, 657.

49. Bennhold, H., and E. Kallee. Comparative studies on the half-life of $\mathrm{I}^{131}$-labeled albumins and non- 
radioactive human serum albumin in a case of analbuminemia. J. clin. Invest. 1959, 38, 863.

50. Bartter, F. C., J. L. Steinfeld, T. Waldmann, and C. S. Delea. Metabolism of infused serum albumin in the hypoproteinemia of gastrointestinal protein loss and in analbuminemia. Trans. Ass. Amer. Phycns 1961, 74, 180.

51. Sell, S., and J. L. Fahey. Relationship between $\boldsymbol{\gamma}$-globulin metabolism and low serum $\boldsymbol{\gamma}$-globulin in germfree mice. J. Immunol. 1964, 93, 81.

52. Humphrey, J. H., and J. L. Fahey. The metabolism of normal plasma proteins and gamma-myeloma protein in mice bearing plasma-cell tumors. J. clin. Invest. $1961,40,1696$.
53. Brambell, F. W. R., W. A. Hemmings, and I. G. Morris. A theoretical model of $\gamma$-globulin catabolism. Nature (Lond.) 1964, 203, 1352.

54. Rausen, A. R., A. Cruchaud, C. W. McMillan, and D. Gitlin. A study of fibrinogen turnover in classical hemophilia and congenital afibrinogenemia. Blood 1961, 18, 710.

55. Sternlieb, I., A. G. Morell, W. D. Tucker, M. W. Greene, and I. H. Scheinberg. The incorporation of copper into ceruloplasmin in vivo: studies with copper $^{64}$ and copper ${ }^{67}$. J. clin. Invest. 1961, 40, 1834.

56. Solomon, A., and T. B. Tomasi, Jr. Metabolism of $\operatorname{IgA}\left(\beta_{2} \mathrm{~A}\right)$ globulin. Clin. Res. 1964, 12, 452. 